ANNA VODICKA

\title{
AERIAL PERSPECTIVES ON PLUMBING, HEATING, AND ELECTRICAL
}

The cat from his low position by the fireplace will only see a few nebulous flecks and stripes, while to the human observer all the colored blotches melt into beautiful, orderly patterns and arabesques... Why the paradox that distance rather than proximity can be a boon for students of buried yesterdays?

- Leo Deuel, Flights into Yesterday: The Story of Aerial Archaeology

A decade before Google Earth was invented, a man with an airplane sold my father an aerial photograph of the shop. The image shows a complex pattern of skinny, rivulet county roads, thick green forest, and spectacularly misshapen bodies of water, patterns we don't see from the zoomed-in point of view of our dirt roads and empty highways, where everything is too close, too flat, and pixelated. From above, you can't see the words AVFCo SUPPLY CO., PLUMBING HEATING \& ELECTRICAL in plastic red letters on the building's beige steel siding. You can't see double glass doors that open into the showroom of cabinets, sinks, and bathtubs, an array of toilet seats, a bidet on clearance, a ceiling full of light fixtures, a wall of drills and saws. It's a gallery of the mundane. Still Life with Power Tools. But in the photo, you see the place from the top, which makes it seem as if Avfco Supply is the center of something - a fixture in the landscape of our unincorporated town, a stony core of some strange fruit painted by an artist whose palette was limited to the cool side of the color wheel.

The image accurately depicts the emptiness of the place, this land of the six-month winter, where folks know the Holy Spirit and harder spirits and depend on both to survive the kind of isolation bred by annual whiteouts. But, as the photograph witnesses, we're saved by blue-blue gold in these parts. So much water, lakes upon lakes, Great Lakes, Superior lakes, chains of lakes strung together in long, irregular links like bulbs of sapphire on string, misshapen turquoise beads on bronze, or some other form of blue collar we wear with Midwestern pride. 
This is northern Wisconsin from a bird's-eye view, as the crow flies, as the tourists fly, straight on through. I remember watching from the dock as the occasional seaplane-an exotic bird-landed on Sugar Camp Lake. They never lingered long before taking off again, and my eyes traced their route across the sky to someplace else. I gawked, too, at the pilots who rented a house on the lake when I was in high school. They were almost never home, but we knew by the sound of their speedboats, fancy machines designed for big wakes, that they had arrived. I watched them with fascination, handsome men with dark tans and the whitest teeth I'd ever seen. Once in a while, they would pull up to our dock on Jet Skis, talk shop with my dad, or if I was alone, they'd talk to me-unless they had visitors, women who looked like they lived in bikinis, and then I listened from a distance to their laughter echoing like loon calls across the lake.

What's absent from the photograph is just that: signs of life. Day signaled by the sound of Dad's key in the lock and Folgers percolating, the smell of the brew mingling with pipe grease and the metallic perfume of tools. Bruce sidling up to the customer at the counter with a hand outstretched and a "Hey der, what kin I do ya fer?" Gene gathering the men for the daily Coin Flip, a simple ritual, a moment of almost ceremonial diversion from stripping pipe; peddling sump pumps; artfully installing countertops, track lighting, and sprinklers; and giving septic advice to tourists from Chicago and New York who hire builders to construct quaint lakeside cabins they'll visit two weeks a year.

Loser of the Flip buys the Cokes that will carry the men through to the freedom hour of noon, when Norm will head to The Café for a refill on coffee and rumors. Dave will drive his Ford truck home, kiss the wife and kids, and down another soda before putting an hour of work in on the new addition. And just as he has for forty years, Dad will leave his Formica desk, leave the books and the inventory and the news of a Home Depot on the way, and drive home. He will drive past the town's other fixtures-Sugar Camp Elementary School and the Town Hall, Schneider's Pub and St. Kunegunda's Church-before turning down Indian Lake Road, a slow, curving route where birch and pine grow so thickly that they make a great archway over the road. He'll pass cabins that have been in families for generations and will come alive in the summer months at their return. He'll pass homes with fresh-cut woodpiles and long gravel driveways. Homes where people have died or had affairs or had legendary Christmas parties. Homes where 
hoses snake into gardens in the summertime and fires blaze on hearths in the winter and porch lights signal that you are welcome. Lives made out of plumbing, heating, and electrical.

There's something to be said for still life, the art of the inanimate. It devotes its eye to the commonplace. When I was a kid, tracing shelves of PVC cement with a feather duster, taking inventory, and answering telephones"Avfco Supply, how may I direct your call?"-I found that kind of art dull. I was too close to see that there is life, still, in strokes and pixels, dimension in shadow and light.

Dad hung the framed photograph on the pegboard wall behind Avfco's cash register, beneath the Ducks Unlimited clock and the surveillance camera that's kept an eye on the place since '89, the year that Barry, a trusted employee, raided the register, and Eddie, a man who was with us from the beginning, a man who was like a son to my father, left without saying goodbye. Eddie fled to Florida, that faraway place of palm trees, juicy red grapefruit, and blazing hot sun we all dream about.

Now, the outside is on the inside, the aerial perspective frozen below a pair of brown-bellied mallards with iridescent green heads that coast on the face of the clock on the wall, birds that would be in Florida this time of year if they knew how to fly. 